\title{
Amino acid and related compound composition in two symbiotic mytilid species from hydrothermal vents
}

\author{
V. Pranal, A. Fiala-Médioni, J. C. Colomines \\ Observatoire Océanologique, laboratoire ARAGO, Université Pierre et Marie Curie - CNRS URA 117, \\ F-66650 Banyuls-sur-mer, France
}

\begin{abstract}
Two species of deep-sea mussels belonging to the genus Bathymodiolus were collected from 5 vent fields distributed over 2 basins of a hydrothermal system in the South Pacific. Free and bound primary amino compounds were analysed in gills and mantles using OPA-HPLC. The method allowed the detection of 32 amino acids and related compounds (AARCs). An undetermined free chemical was found at high levels (up to $30 \%$ of the total free AARCs) in vent mussel tissues. This amino compound is presumed to be an end-product from specific metabolism occurring in vent mussels. Except for this unknown compound, comparison of the biochemical composition between vent and littoral mussels revealed that the general nitrogenous requirement as well as the endogenous metabolic pathways of the main amino acids seem to be similar for the 2 mussel types. Ultrastructural observations indicated that these deep mussels harbour bacteria in their gills. Indices of high metabolic rates found in these organs appear to be related to the presence of endobacterial. It seems that symbionts could provide a preponderant fraction of essential amino acids to their host. In particular, free thiotaurine displayed high concentrations (up to $13 \%$ of the total free AARCs). This sulphur-containing compound could be involved in a specific metabolism related to toxic forms of sulphur. Variations of the AARC composition between the 2 vent mussel species do not appear to be species related but appear to be due to environmental constraints. As shown by stress indices, deterioration of the physiological condition in these mussels is directly linked to the quantity and/or the quality of the hydrothermal vent emissions.
\end{abstract}

KEY WORDS: Amino acids and related compounds - Symbiotic mussels · Sulphur-oxidizing bacteria * Hydrothermal vent . Physiological index

\section{INTRODUCTION}

The bivalves Mytilidae have a world-wide distribution with a great majority of species occurring intertidally in littoral and shallow sublittoral ecosystems (Russell-Hunter 1983, Koehn 1991). This family, like most other marine invertebrates, depends for its food supplies on the phytoplanktonic primary production that constitutes the base of the general marine foodweb (Jørgensen 1990). Until recently, mussels were considered to be exclusively sedentary, filter-feeding organisms living on plankton and organic detritus (Bayne 1976, Allen 1983), free bacteria (Prieur 1981, Birkbeck \& McHenery 1982) or dissolved organic solutes (Stephens 1972, Melaouah 1990). Discovery of a new fauna associated with deep hydrothermal vents has shown that at least 1 genus, Bathymodiolus, can use another nutritional strategy (Fiala-Médioni et al. 1986a, Fiala-Médioni \& Le Pennec 1987, Fiala-Médioni 1988). Species of this genus were found associated with deep, active tectonic areas in the Atlantic and Pacific (Fiala-Médioni 1988). These environments, which often correspond to the aphotic zone, are depleted of photosynthetic carbon but are full of energy-rich chemicals and sometimes highly toxic substances like hydrogen sulphide $\left(\mathrm{H}_{2} \mathrm{~S}\right)$ or heavy metals (Childress \& Fisher 1992). All of the Bathymodiolus species critically examined to date harbour autotrophic prokaryotes in their gill cells. These bacteria appear to be able to use sulphur or methane to power carbon fix- 
ation, resulting in a net input of endobacterial carbon in the host tissues (Fisher et al. 1987, 1993, FialaMédioni \& Felbeck 1990). Studies performed on symbiotic mussels and other bivalve-bacteria associations show that the transfer of newly synthetized bacterial carbon to the host can follow 2 distinct pathways. The organic carbon could be translocated to the bivalve cells from living bacteria (Felbeck 1983, Fisher \& Childress 1986) or transferred from the symbionts to the host through phagocytotic processes (Fiala-Médioni et al. 1986b, 1989, 1994, Fisher \& Childress 1992).

Amino acids and related compounds (AARCs) including thioamines (such as taurine, hypotaurine or thiotaurine) and amino sugars (such as glucosamine or muramic acid) account for an important part of the living material. In a bound form, some of them make up proteins involved in cell structures and specific cellular activities like enzyme reactions or energy storage (Gabbott 1976, Lehninger 1981, Phillips 1984). Free amino acids are found in high concentrations in the tissues of marine invertebrates where they act mainly as osmotic regulators of the cells (Livingstone et al. 1979, Shumway \& Youngson 1979, Bishop et al. 1983). In addition to these general features, some authors have suggested that in bacteria-bivalve symbiotic models, specific compounds with low molecular weights such as free amino acids could play a role in energetic (Fiala-Médioni et al. 1986b, Albéric \& Boulègue 1990) or nutritive transfers (Felbeck \& Childress 1983) between endosymbionts and their hosts as well as in detoxification mechanisms (Albéric 1986, Albéric \& Boulègue 1990).

Analysis of AARC composition can allow the biochemical plasticity of these marine organisms to be defined and the variation in their biochemical composition according to nutritional strategy to be estimated. AARC analysis was performed both in symbiotic and heterotrophic mussels in order to characterize endobacterial markers and to detect specific putative amino compounds involved in the relationships between symbiotic bacteria and their hosts.

\section{MATERIALS AND METHODS}

Station locations and description. Specimens of Bathymodiolus were collected in the hydrothermal vent fields of the back arc basins in the South Pacific during the 'Biolau' (Lau Basin, 1989) and 'Yokosuka' cruises (North Fiji Basin, 1991).

Three sites in the Lau Basin were sampled. The first site was a hot site, Vailili Field $\left(22^{\circ} 13^{\prime} \mathrm{S}, 176^{\circ} 36^{\prime} \mathrm{W}_{i}\right.$ 1707 to $1764 \mathrm{~m}$ ), which is one of the most active hydrothermal fields known. Temperature of the fluids venting from black and white smokers exceeded $350^{\circ} \mathrm{C}$,
$\mathrm{pH}$ was about 2 and salinity was higher than that of sea water (Fouquet et al. 1991, Ishibashi et al. 1994). The temperature of the water surrounding the mussels and bispecific gastropod clumps, located at the basis of the smokers, ranged from 2 to $33^{\circ} \mathrm{C}$ (Desbruyères et al. 1994). The second site sampled was a warm site, HineHina $\left(22^{\circ} 32^{\prime} \mathrm{S}, 176^{\circ} 43^{\prime} \mathrm{W}\right.$; 1832 to $\left.1887 \mathrm{~m}\right)$ located $50 \mathrm{~km}$ further south on the Valu Fa Ridge. It was characterized by the absence of smokers; the temperature around the mussel beds fluctuated from 1.6 to $18.7^{\circ} \mathrm{C}$ (Desbruyères et al. 1994) and the surrounding sea water showed methane enrichment of up to $4.4 \mathrm{nl} \mathrm{l}^{-1}$ (Fouquet et al. 1991). Lastly, to the south of the Hine Hina site a cold site, Site Sud (1885 m), was also sampled; at this site, fluids around mussels were at ambient water temperature (Desbruyères et al. 1994).

In the North Fiji Basin, samples were collected at 2 sites. The first one, Kayo $\left(16^{\circ} 59^{\prime} \mathrm{S}, 173^{\circ} 43^{\prime} \mathrm{W}\right.$; $1977 \mathrm{~m})$, was characterized by intensive emissions of fluids with high temperatures $\left(296^{\circ} \mathrm{C}\right)$, strong $\mathrm{H}_{2} \mathrm{~S}$ concentrations $\left(4.0 \mathrm{mmol} \mathrm{kg}{ }^{-1}\right)$ and $\mathrm{pH}$ of the end member fluids of about 4.7 (Ishibashi et al. 1994). Fauna at the basis of the smokers was composed of high biomasses of symbiotic bivalves and gastropods. The second site, Sunset $\left(18^{\circ} 49^{\prime} \mathrm{S}, 173^{\circ} 30^{\prime} \mathrm{W} ; 2716 \mathrm{~m}\right)$, seemed to be in a phase of declining activity with cold fluxes of water (about $5^{\circ} \mathrm{C}$ ) seeping through patches of living mussels surrounded by numerous empty shells.

Mussels collected at the 3 sites of Lau Basin and at Kayo were identified as Bathymodiolus brevior and those collected at Sunset as B. elongatus (Von Cosel et al. 1994).

The filter-feeding bivalve Mytilus galloprovincialis was used as a reference and sampled at a depth of $20 \mathrm{~m}$ in the Golfe du Lion in the western Mediterranean Sea, Banyuls (France).

Sample extraction. The mantles and gills of the mussels were dissected immediately after arrival on board. Samples were fixed and kept in liquid nitrogen until reaching the laboratory where they were freeze-dried.

Free AARC extraction was performed by adding $500 \mu \mathrm{l}$ of iced $70 \%$ ethanol and $100 \mu \mathrm{l}$ of $1.5 \mathrm{mM}$ homoserine (as an internal standard) to $30 \mathrm{mg}$ of ground tissue. After extraction for $1 \mathrm{~h}$ on ice, the solution was centrifuged at $12500 \mathrm{rpm}(10000 \times \mathrm{g})$ for $10 \mathrm{~min}$. The supernatant was then removed and placed under vacuum. After evaporation, the free AARC pellets were diluted in distilled water and filtered on $0.2 \mu \mathrm{m}$ pore size membranes.

Total AARC extraction was performed by adding $1.5 \mathrm{ml}$ of $6 \mathrm{~N}$ hydrochloric acid and $100 \mu \mathrm{l}$ of $1.3 \mathrm{mM}$ homoserine to 5 to $7 \mathrm{mg}$ of ground tissue in hydrolysis tubes. After hydrolysis under vacuum at $100^{\circ} \mathrm{C}$ for $24 \mathrm{~h}, 1.5 \mathrm{ml}$ of $6 \mathrm{~N} \mathrm{NaOH}$ was added, $1 \mathrm{ml}$ of this solution was then removed and mixed with $2 \mathrm{ml}$ of $0.4 \mathrm{M}$ 
$\mathrm{H}_{3} \mathrm{BO}_{3}, \mathrm{pH}$. The buffered solution obtained was filtered on $0.2 \mu \mathrm{m}$ pore size membranes.

During hydrolysis, asparagine and glutamine were converted into aspartate and glutamate respectively so, in this study, hydrolysed aspartate represents the sum of aspartate and asparagine and hydrolysed glutamate the sum of glutamate and glutamine. Because of its lability under hydrochloric acid, tryptophane is not mentioned among the total AARC.

Differences between hydrolyzed and free AARCs were assumed to be measurements of bound AARC associated with either intact or large fragments of proteins or other polypeptidic structures.

HPLC analysis. All the solvents and salts were of analytical-reagent grade. Amino acids and other amino compounds were purchased from Sigma Chemical Co.

A mobile binary phase system was used for this study. Solvent A was tetrahydrofuran-methanol-0.05 M sodium acetate $\mathrm{pH} 6.8(0.5: 19.5: 80$, by vol. $)$; solvent $B$ was methanol-0.05 $\mathrm{M}$ sodium acetate $\mathrm{pH} 6.8(8: 2$, by vol.). The gradient is given in Table 1 . Flow rate was $1 \mathrm{ml} \mathrm{min}{ }^{-1}$. The derivatization was conducted according to Mopper \& Lindroth (1982). The methanolic solution was made by dissolving $50 \mathrm{mg}$ ophthalaldehyde (OPA) in $1 \mathrm{ml}$ of methanol plus $50 \mu \mathrm{l}$ of mercaptoethanol. The procedure for derivatization was as follows: $100 \mu$ of standard mixture or biological sample were mixed with $10 \mu$ l of $1 \mathrm{mM} \mathrm{S}$-methylcystein (SMC) as an external standard and $405 \mu \mathrm{l}$ of $0.8 \mathrm{M}$ boric acid at $\mathrm{pH} 9.5 ; 5 \mu \mathrm{l}$ of the methanolic solution and $5 \mu \mathrm{l}$ of $0.8 \mathrm{M}$ borate buffer at $\mathrm{pH} 12.5$ were then added. This solution was mixed thoroughly and, 2 min after the start of the derivatization, $100 \mu$ were injected into a C18 reverse-phase column $\left(\mathrm{T}=32^{\circ} \mathrm{C}\right)$. AARCs were detected by fluorescence (360 $\mathrm{nm}$ for excitation and $455 \mathrm{~nm}$ for emission)

Transmission electron microscopy. After dissection, gill samples were fixed with glutaraldehyde final concentration $3 \%$ ) in $0.4 \mathrm{M}$ cacodylate buffer at $\mathrm{pH} 7.8$. After rinsing in the same buffer, they were post-fixed in osmium tetroxide (final concentration $1 \%$ ), dehydrated in a graded ethanol series followed by propylene oxide, embedded in Epon, and sectioned for transmission electron microscopy (TEM). The sectioned material was stained with uranyl acetate and lead citrate. A Jeol $100 \mathrm{CX}$ transmission microscope was used for the observations.

Table 1 . Elution gradient of the binary phase system used for the HPLC analysis

\begin{tabular}{llllllllll} 
Eluent A (\%) & 0 & 10 & 10 & 14 & 14 & 50 & 50 & 100 & 0 \\
\hline Time (min) & 2.1 & 5.1 & 17 & 20 & 25 & 30 & 34 & 52 & 62
\end{tabular}

\section{RESULTS}

\section{AARC composition of Mytilus galloprovincialis}

The composition of bound AARCs (Table 2) was quite homogeneous. Bound AARC concentrations ranged from $1754 \mu \mathrm{mol} \mathrm{g}{ }^{-1}$ dry wt for the mantles to $2744 \mu_{\mathrm{mol} \mathrm{g}}^{-1}$ dry wt for the gills. The proportion of each compound was very similar in gills and mantles. Percentages varied between $1.05 \%$ (glucosamine) and $17.47 \%$ (aspartate), with percentages above 10\% being found for aspartate, glycine and glutamate. Essential amino acids (EAAs) accounted for 39.34\% (gills) and $41.31 \%$ (mantles) of the total bound AARC concentration.

The total free AARC concentration ranged from $616 \mu \mathrm{mol} \mathrm{g}{ }^{-1}$ dry wt (gills) to $710 \mu \mathrm{mol} \mathrm{g}{ }^{-1}$ dry wt (mantles). The free AARC composition (Table 3) was characterized by the predominance of taurine, glycine and alanine, accounting for $80.35 \%$ of the total free AARC concentration in gills and $64.06 \%$ in mantles. Aspartate, glutamate, hypotaurine and arginine were all greater than $1 \%$, both in gills and mantles. The sum of EAAs was higher in mantles $(15.12 \%)$ than in gills $(4.41 \%)$. Arginine and threonine represented the most important proportions of the EAAs, and tryptophane and methionine the minor ones. Two specific compounds were detected: traces of the bacterial amino acid $\beta$-aminoglutarate (both in gills and mantles) and the thiosulphonic amine thiotaurine (the percentage of this ranged from $0.06 \%$ of the total free AARC concentration for mantles to $0.23 \%$ for gills). The thiotaurine: thiotaurine + hypotaurine ratio (Fig. 1) was very low both in gills and mantles ( 0.06 and 0.03 , respectively).

The taurine: free glycine ratio (Table 3 ) was higher in gills (3.44) than in mantles (1.20). Organ distribution was reversed for the threonine + serine concentration $\left(8.26 \mu \mathrm{mol} \mathrm{g} \mathrm{g}^{-1}\right.$ in gills and $60.96 \mu \mathrm{mol} \mathrm{g}{ }^{-1}$ in mantles; Table 3)

\section{AARC composition of Bathymodilus spp.}

The bound AARC composition (Table 2) of all the vent mussels was very stable and similar to those of the filterfeeding mussels. Concentrations ranged from 2699 to $3472 \mu_{\mathrm{mol} \mathrm{g}}{ }^{-1}$ dry wt for gills and from 2346 to 4219 $\mu \mathrm{mol} \mathrm{g}^{-1}$ dry wt for mantles. The sum of the EAAs varied from 36.93 to $43.03 \%$ of the total bound AARC concentration for gills and from 41.39 to $42.62 \%$ for mantles. Among the putative bacterial bound AARCs, no diaminopimelate or lanthionine was detected. Glucosamine concentrations in gills were higher in vent mussels than in littoral mussels (from 1.30 to $2.61 \mu \mathrm{mol}$ $\mathrm{g}^{-1}$ dry wt in vent mussels) and lower for mantles (traces 
to $0.60 \mu \mathrm{mol} \mathrm{g}^{-1}$ dry wt in vent mussels) with the lowest concentrations found in North Fiji Basin mussels.

Free AARC concentrations ranged from 548 to $899 \mu^{m o l ~ g^{-1}}$ dry wt for gills and from 516 to $613 \mu \mathrm{mol} \mathrm{g}{ }^{-1}$ dry wt for mantles. Free AARC composition (Table 3) was characterized by the predominance of glycine, taurine, alanine and an unknown compound named X2, coeluting with muramic acid which displayed higher concentrations in mantles than in gills. Differentiation of this unknown compound from muramic acid was performed by using the lability of lactoyl ether of muramic acid in an alkali medium. Some samples previously extracted with ethanol were subjected to mild alkaline hydrolysis to release D-lactic acid from the muramic acid (Moriarty 1983). After this treatment the peak was still present in the chromatograms, confirming it did not correspond to the amino sugar.

In all the mussels studied, aspartate and glutamate proportions were quite constant, with lower values than those found in Mytilus galloprovincialis tissues for the former (from 0.37 to $2.68 \%$ of total free AARC concentration) and values of the same order for the latter (from 1.96 to $4.35 \%$ of the free AARC concentration) for all Bathymodiolus brevior samples.

Small amounts of the bacterial amino acid $\beta$-aminoglutarate were present in vent mussel tissues, both in gills and mantles. No other specific bacterial compounds were detected.

The sums of the free EAA percentages were very similar for all the mussels collected in Lau Basin. These sums were higher for samples from this basin (from 12.70 to $12.88 \%$ in gills and from 5.03 to $5.59 \%$ in mantles) than for the Fiji Basin samples (from 5.12 to $7.36 \%$ in gills and from 3.87 to $4.33 \%$ in mantles). Higher percentages of free EAAs in vent mussel gills than in mantles seem clearly to be related to endobacterial presence. Except for the fact that the sum of free EAAs is higher in gills than in mantles, these amino acids displayed the same

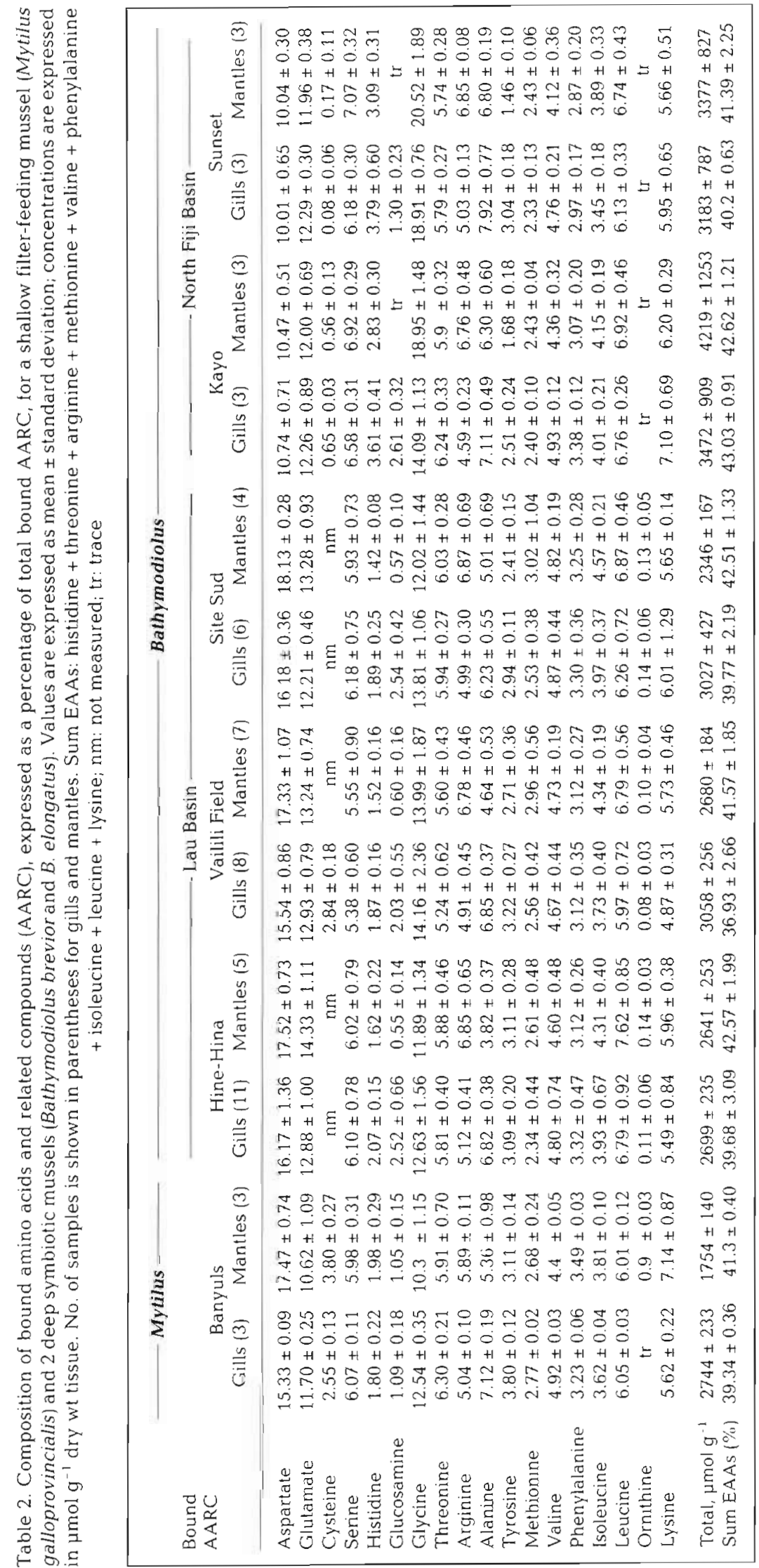




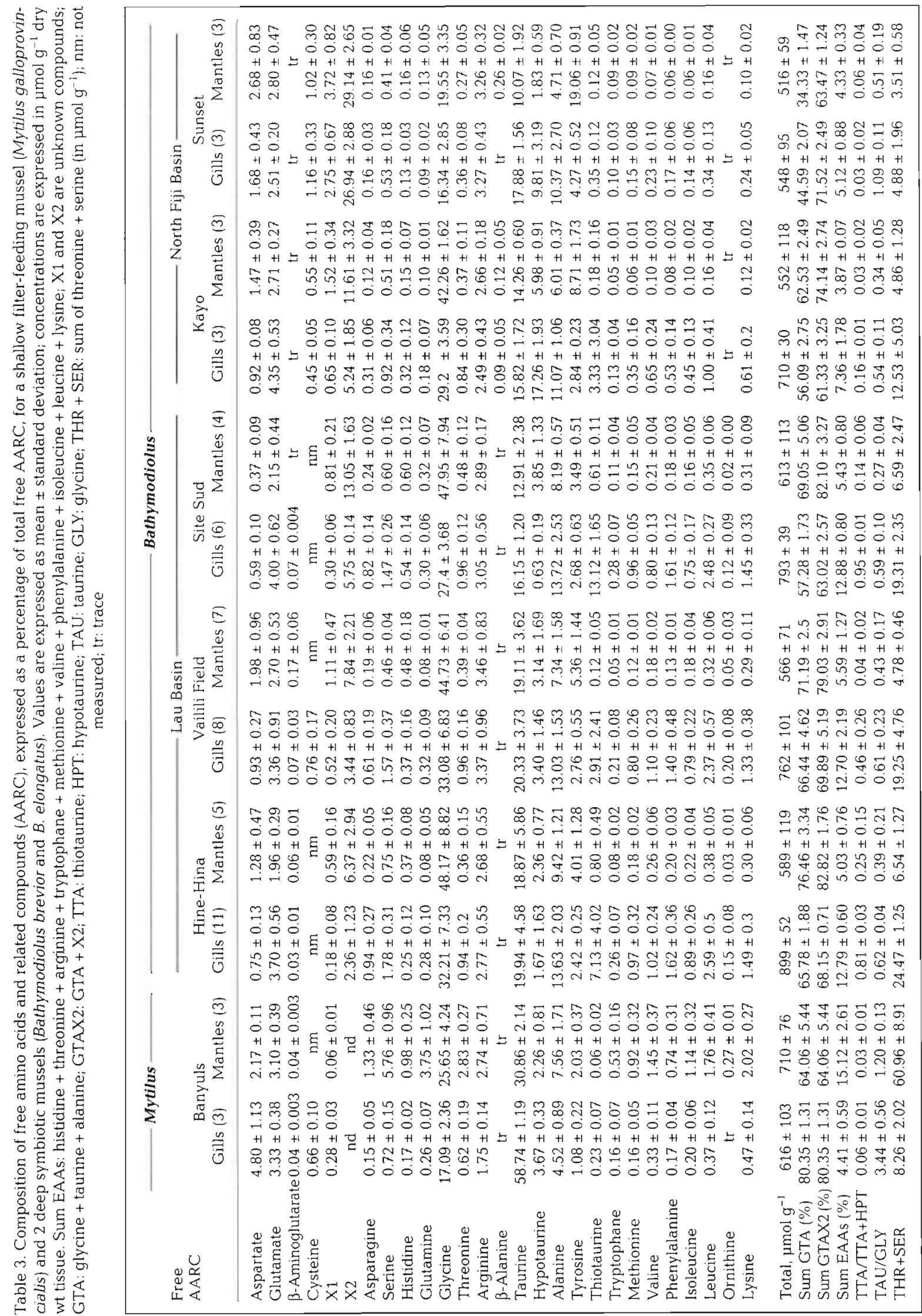


TTAU:

TTAU+HYPT

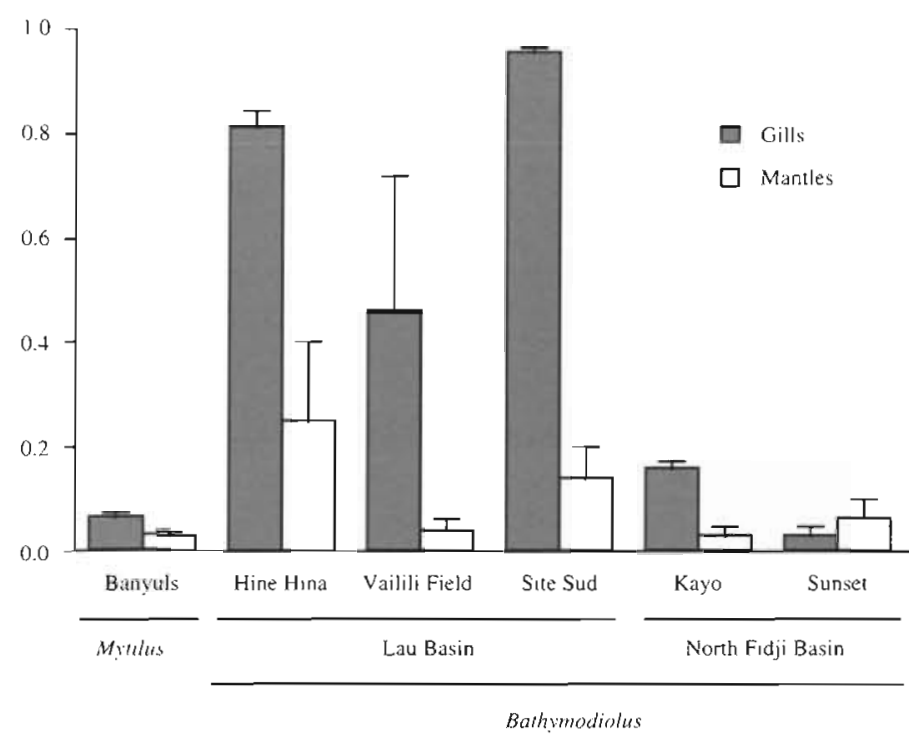

Fig. 1. Thiotaurine:thiotaurine + hypotaurine ratio for the littoral mussel Mytilus galloprovincialis (Banyuls) and for deep hydrothermal vent mussels Bathymodiolus brevior and $B$. elongatus collected at 3 sites of the Lau Basin (Hine Hina, Vailili Field and Site Sud) and 2 sites of the North Fiji Basin (Kayo and Sunset)

In all the vent mussel samples, the free taurine: free glycine ratio (Table 3 ) was higher in gills than in mantles. Values were homogeneous for all the sites except for Sunset where the ratio found was higher. The threonine + serine concentrations (Table 3 ) displayed the same pattern: values were higher in gills than in mantles and were similar between sites, except for the vent mussels collected at Sunset. For the latter samples, the threonine + serine concentration was lower than in the other vent mussels. This difference was particularly pronounced in gills.

\section{DISCUSSION}

\section{General features common to all mytilids}

The composition of the most common free and bound AARCs of vent mussels is globally similar to that previously reported for littoral mytilids (Livingstone et al. 1979, Shumway \& Youngson 1979, Aftab 1988, Zhang et al. 1991).

Bound AARC ratios show weak intra- and inter-specific variability among all the samples analyzed in this study; this homogeneity is very clear with respect to the sum of bound EAA percentages. These values are consistent with

pattern in vent mussel tissues as in littoral mussel tissues. In all the vent mussels, tryptophane was found in lower proportions, while arginine displayed the major percentages with very stable values in both gills and mantles (from 2.66 to $3.46 \%$ of the total free AARC). When the proportions of the other free EAAs were very low (see vent mussels collected in the North Fiji Basin), arginine represented the main proportion of this group of compounds.

Among the free sulphur AARCs, cysteine was not measured in all the samples, but available values for the vent mussels are of the same order as those of filter-feeding bivalves. The percentage of methionine followed the same pattern as the other EAAs and was not significantly different from the percentage found in Mytilus galloprovincialis tissues. Thiotaurine was present in high proportions in gills of the symbiotic mussels (from $0.35 \%$ for Sunset site mussels to $13 \%$ of the total free AARC for those of Site Sud). Values of this thiosulphonic compound varied more in vent mussel tissues than the mean values of other amino compounds and also more than the values of this compound in littoral mussel tissues. Except for mussels collected at Sunset, the thiotaurine:thiotaurine + hypotaurine ratio in gills (Fig 1) was significantly higher in vent mussels than in littoral mussels, with maximal values observed in Lau Basin samples. other studies pointing out that marine invertebrates exhibit fairly consistent bound EAA distribution in their tissues (Phillips 1984). The fact that bound EAAs occur in similar quantities in symbiotic and filter-feeding mussels or in other heterotrophic marine invertebrates indicates that physico-chemical data of the environment and feeding strategies have little effect on general biochemical composition, and therefore on the basic nitrogen needs, of marine invertebrates

Free AARC composition is characterized by a predominance of taurine, glycine and alanine. These AARCs have been reported to play an important role in osmotic regulation mechanisms (Baginski \& Pierce 1977, Livingstone et al. 1979, Shumway \& Youngson 1979). Compared to Mytilus, a high proportion of free glycine is observed in Bathymodiolus spp. tissues this amino acid is known to have a rapid turn-over compared to that of taurine (Baginski \& Pierce 1975 1977, Livingstone et al. 1979). Differences in the taurine: glycine ratio between littoral and vent mussels could be explained by the fact that bivalves living near hydrothermal vents can be momentarily exposed to short-term salinity variations. In this case, the fast osmoregulation response of glycine is more appropriate than that of taurine, the metabolism of which corresponds mainly to long-term salinity fluctuations specific to littoral environments. 
Some authors consider the preponderant organic osmoregulators to be metabolic end-products of the bivalve metabolism (Campbell \& Bishop 1970, Allen \& Garrett 1971, Bayne et al. 1985). The fact that they constitute the greater part of the free AARC pool, both in filter-feeding and in symbiotic bivalves, indicates that despite their difference in nutritional strategies, the general nitrogenous metabolic pathways involved in these mytilids are similar.

\section{Endosymbiotic bacterial markers}

Traces of free $\beta$-aminoglutarate were detected in Bathymodiolus tissues; this compound is considered to have a prokaryotic origin (Henrichs \& Cuhel 1985) and has been used as a marker of some free (Mopper \& Dawson 1986) or symbiotic (Dando et al. 1986) bacterial presence. As low levels were observed in the symbiotic mussels, both in gills and mantles, and as filterfeeding bivalves also contained small amounts of this compound, probably related to free living bacteria ingestion or gut microflora production, $\beta$-aminoglutarate cannot be considered here as a specific marker of endobacteria associated with the vent mussels.

Amino acids like lysine, diaminopimelate, lanthionine or ornithine as well as specific amino sugars like muramic acid and glucosamine make up the eubacterial cell wall, called peptidoglycan (Schleifer \& Kandler 1972, Braun et al. 1973, Brack et al. 1984, Hartmann \& Konig 1990). A high level of free diaminopimelate was found in all the organs of the symbiotic giant clam Calyptogena magnifica from a hydrothermal vent site at the Galapagos rift (P. Albéric pers. comm.). Bacteria associated with the 2 Bathymodiolus species analyzed in this study do not present peptidoglycan made up of such a specific compound or of its sulphured homologue, lanthionine. Although muramic acid occurs in all eubacterial species, it could not be taken as evidence in this study because it eluted with the same retention time as the unknown compound $\mathrm{X} 2$. On the other hand bound glucosamine was detected in all the bivalves analyzed. This compound occurs in both eukaryotic and prokaryotic cells (Lehninger 1981) but it constitutes an important part of the cell wall of microorganisms (Schleifer \& Kandler 1972, Hebeler \& Young 1976). While in Mytilus galloprovincialis the same amounts of bound glucosamine were found in gills and mantles, in Bathymodiolus spp. from Lau Basin, amounts in gills were about 4 to 5 times higher than in mantles. We assume this difference between organs to be related to endobacterial presence in the gills of vent mussels. This hypothesis is supported when the levels of glucosamine in vent mussel gills are compared: the weakest levels of this compound were found in gills of Sunset mussels which correspond with vent mussels having the lowest endosymbiotic biomass as observed in TEM (Fig. 2).

Free AARC composition of symbiotic mussel gills is closely related to that of non-symbiotic mussel mantles while free AARC composition of symbiotic mussel mantles is similar to that of non-symbiotic mussel gills. Gills of filter-feeding bivalves are mainly food collecting and gas exchange structures (Jørgensen 1990). In contrast, mantles present high rates of synthesis and important storage potential for synthetized or assirnilated substances (De Zwaan \& Van Marrewijk 1973, Bayne et al. 1976, De Zwaan 1983). The inversion of the gill-mantle characteristics between littoral and vent mussels appears to be related to the presence of endosymbionts in vent mussel gills. This fact is particularly clear when the sum of free EAAs is analysed. Most bacteria synthetize EAAs; e.g. these compounds account for about $60 \%$ of the free AARCs of Escherichia coli (authors' unpubl. results). It is generally accepted that enteric microbes present in animals could potentially supply some EAAs to their host (Phillips 1984). In the littoral mussel, the higher levels of free EAAs in mantles than in gills could be related to the important metabolic function of this organ. In the vent mussels, the higher proportion of free EA.As in gills than in mantles is probably related to the presence of bacterial symbionts. In contrast with the filterfeeding bivalves, vent mussel gills appear to be organs where important syntheses occur through endosymbiotic metabolism

\section{Specific component related to vent mussel metabolism}

The unknown compound $\mathrm{X} 2$ was detected in both species of vent mussels, irrespective of geographical location or sampling site. As no trace was found in littoral mussel tissues, in other symbiotic bivalves such as vesicomyid and lucinid clams or in symbiotic gastropods collected at the same sites (authors' unpubl. results), this compound appears to be specific to the Bathymodiolus genus. The fact that X2 concentrations were higher in mantles where no symbiotic bacteria occur and that the mantle is the site of most syntheses in bivalves (Bayne et al. 1976, De Zwaan 1983) supports the idea that this compound is related to bivalve metabolism more than to endobacterial syntheses. This hypothesis is endorsed by the fact that higher proportions of the unknown compound were found in the tissues of vent mussels collected at the less active sites (i.e. Sunset) where the bivalves presented the smallest symbiotic biomass in gills (Fig. 2) and where endosymbiotic contribution to the nutrient supply of the host is probably less important than at the other sites. The 


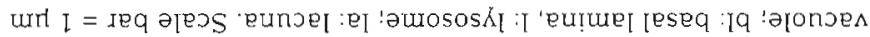

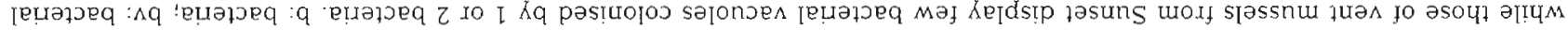

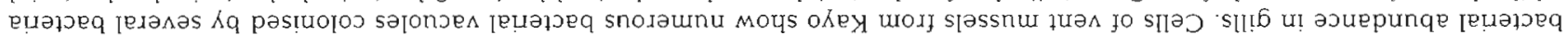

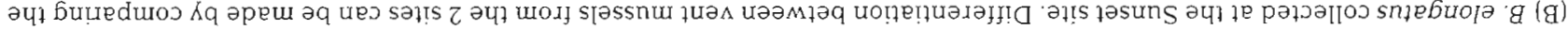

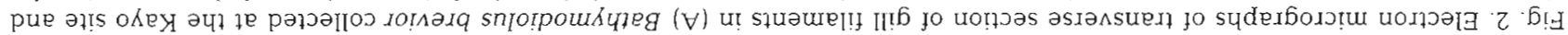
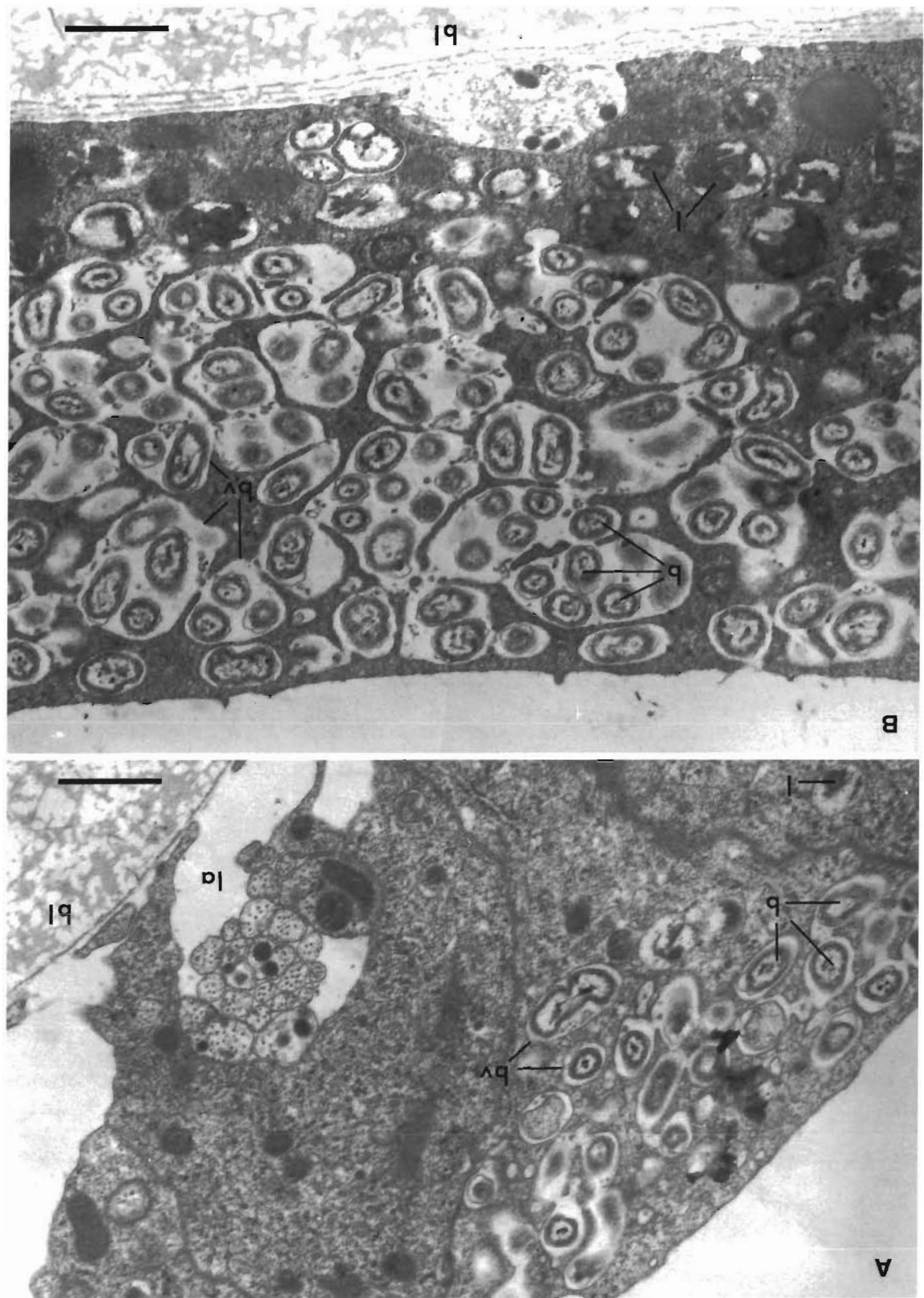
unknown compound X2 was present in vent mussel tissues only in free form and highest percentages were found in specimens depleted of the 3 main amino compounds (taurine, glycine and alanine) related to osmoregulation mechanisms. Comparison between Mytilus galloprovincialis gills and Bathymodiolus spp mantles and vice versa shows that the sum of taurine glycine, alanine and $\mathrm{X} 2$ in vent mussel tissues is quite similar to the sum of the 3 main compounds in the tissues of littoral mussels. If we consider that the main amino compounds involved in osmotic mechanisms are metabolic end-products (Campbell \& Bishop 1970 Allen \& Garrett 1971, Bayne et al. 1985), it can be assumed that the unknown compound X2 is an endproduct (therefore with a weak energy potential) of a specific metabolic pathway of the Bathymodiolus spp. bivalves.

\section{Evidence of metabolism related to sulphur}

Symbiotic mytilids are a group variable with respect to the symbionts they harbour (Fisher et al. 1987, 1993). According to the geological context and the chemical availability, methanotrophic or sulphur-oxidizing endosymbiotic bacteria or both have been described in different mussel species (Cavanaugh et al. 1992, Fisher et al. 1993). To our knowledge, most of the hydrothermal vent mussels described until recently have sulphur-oxidizing bacteria in their gills. Although the source of thiosulfate is a point which has to be clarified, because no determinations of this anion in vent water have been reported, Belkin et al. (1986) and Fisher et al. (1987) have shown that this chemical stimulates carbon fixation in hydrothermal and cold seep mussels bearing sulphur-oxidizing bacteria.

Among the sulphur-containing organic compounds analyzed in this study, methionine and cysteine of Bathymodiolus spp. tissues do not present values significantly different from those of Mytilus galloprovincialis and high taurine rates might be related to osmoregulation mechanisms. However, thiotaurine values are significantly higher in Bathymodiolus spp. tissues than in those of $M$. galloprovincialis, especially in gills. High levels of this compound were also detected in tissues of the tube worm Riftia pachyptila (Albéric 1986), and the giant clam Calyptogena magnifica (Albéric \& Boulègue 1990), which are both invertebrates living in sulphur-rich areas, associated with sulphur-oxidizing bacteria. As a result, thiotaurine appears to be a general and characteristic feature of symbiotic associations based on sulphur-oxidizing processes.

The 2 Bathymodiolus species display a strong variability of thiotaurine values compared with other free AARCs and with thiotaurine concentrations in Mytilus galloprovincialis. High concentrations and great variability support the idea that this compound is involved in a specific and fast turn-over metabolism, different to that involved in osmoregulation mechanisms. Although the catabolic route for taurine and hypotaurine has not been established in filter-feeding bivalves, the gut and its microflora could be both the source and site of their catabolism (Awapara 1976, Bishop et al. 1983). On the other hand, formation of thiotaurine as a byproduct of these processes has been reported (Allen \& Garrett 1971, Cavallini et al. 1979). In symbiotic mussels, autotrophic bacteria could support these syntheses and, as previously proposed by Albéric \& Boulègue (1990), reversible trans-sulphuration reactions between sulphinics (hypotaurine) and thiosulphonics (thiotaurine) may actively participate in the transport of reduced forms of sulphur within the tissues. In this case, endosymbiotic bacteria might help the bivalves to live in a toxic environment, providing substances like hypotaurine able to bind toxic sulfhydryl groups to give inactive sulphured organic compounds like thiotaurine. Accumulation of thiotaurine in gill tissues could then serve as energy for the sulphur-oxidizing bacteria associated with symbiotic mytilids. Under this hypothesis, the thiotaurine: thiotaurine + hypotaurine ratio (Fig. 2) could reflect the availability of reduced organic compounds enriched with sulphur. This ratio should indicate, in the gills of Lau Basin mussels, a good potential supply of highly energetic compounds for the thiotrophic endosymbionts

\section{Variation of the physiological condition index in the vent mussels}

Fisher \& Childress (1992) consider that among marine habitats the chemical environment of hydrothermal vents is most comparable to highly polluted habitats'. Several authors have tried to correlate AARC composition of marine invertebrates to a stress situation such as anthropogenic inputs or other drastic variations of the environmental conditions. Some indices have been suggested to be of use in describing deterioration of physiological conditions. Jeffries (1972) found that the total free amino acids as well as the taurine : free glycine molar ratio in tissues of Mercenaria mercenaria could be used as stress indices, the former decreasing and the latter increasing with stress. In Crassostrea gigas tissues, Riley (1980) recorded a significant correlation between the decrease in the total percentage of free EAAs and an increase in starvation time. Free threonine + serine concentration has also been proposed as a stress indicator by Bayne et al. (1985); in this case, low values of the sum of these amino acids indicate a deterioration of environmental conditions. 
Because most of these studies have been empirical and have not investigated the fate of the compounds, stress index comparison between such dissimilar bivalves as shallow filter-feeding and deep symbiotic mussels appears delicate. Nevertheless a general feature is that most of these index values in gill vent mussels are closely related to those of littoral mussel mantles and vice versa. If this concordance is kept in mind, values of the total free AARC and the sum of free EAAs in Bathymodiolus brevior tissues reveal the good nutritional quality of the symbiotic associations compared to the filter-feeding bivalve.

Among the free EAAs, arginine is found in the highest proportions and this in all types of mussels, in gills as well in mantles. Little is known on arginine metabolism in molluscs; in most mammals, this compound is considered to be an essential amino acid because its rate of formation is too slow to satisfy the requirement for protein synthesis (Gabbott 1976). The guanidino group of arginine can be used in a series of transamidinase reactions for the biosynthesis of a number of putative phosphogens. For this reason, this amino acid plays a central role in the metabolic economy of most molluscan species (Bishop et al. 1983). The high concentrations of this compound in vent mussels seem to indicate the good nutritional status of these bacteriabearing bivalves.

In the Lau Basin, differences in hydrothermal activity are obvious, with 1 site (Hine Hina) showing strong activity characterized by the presence of high temperature smokers and a high and diversified biomass of symbiotic invertebrates including mussels and 2 gastropod species. Fifty kilometres further south, at the 2 low temperatures sites (Vailili Fields and Site Sud), activity seemed less intensive. These sites are distinguished from Hine Hina by an absence of smokers and symbiotic gastropods. Stress indices as well as free and bound AARC composition of all the mussels collected at Lau Basin are qualitatively and quantitatively very similar. These similarities seem to indicate that chemical conditions and/or symbiotic bacteria species associated with Bathymodiolus brevior are the same for the 3 sites of Lau Basin despite different external manifestations of hydrothermal activity.

In the North Fiji Basin, although the Bathymodiolus specimens collected at Sunset belong to a species other than that of the highly active Kayo site, high stress index values in Sunset mussels seemed due to environmental conditions. In situ observations indicate very poor hydrothermal activity at Sunset with only a few cold water seepages and patches of living mussels surrounded by numerous empty shells. This site could correspond to a declining stage of the Mussel Valley site (described in Desbruyères et al. 1994), discovered 2 yr before during the Starmer Cruise. Compared with
Kayo mussels, Sunset mussels presented very thin mantles with an emaciated appearance and weaker lipid reserves (authors' unpubl. results). Gill cells of these mussels were composed of numerous empty vacuoles with less endobacteria than in the gills of Kayo mussels (Fig. 2). The low total free amino acid pool, the sum of the free EAAs and those of the threonine + serine concentrations reflect this poor physiological state probably related to starvation.

Mussels collected at the Kayo site of the North Fiji Basin and at the 3 sites of the Lau Basin belong to the same species. Nevertheless comparison of the stress indices (i.e. the sum of the total free AARC, of the EAAs and those of the threonine and serine concentrations) indicate that the Bathymodiolus spp. from Lau Basin were in better condition than those from Fiji Basin. Distinction between basins was marked with $B$. brevior from Kayo and deeply evident with $B$. elongatus from Sunset. Three hypotheses could explain the differences observed between the 2 basins. (1) Some authors have shown the vent mussels to be able to use an heterotrophic nutritional strategy (Fiala-Médioni et al. 1986b, Fiala-Médioni 1988, Page et al. 1991). In the Lau Basin, the organic carbon concentration of the surrounding water would be higher than in Fiji Basin, allowing a nutritional supply by filtration. (2) Hydrothermal waters venting from Fiji Basin would be enriched with more toxic compounds than those of Lau Basin. (3) Supply of energetic compounds like sulphide or thiosulfate would not be sufficient in Fiji Basin (low concentrations or weak hydrothermal flux) to support an optimal development of the symbiotic bacteria. The 2 basins are at the same depth and are within the same reach of the coast. Thus, the biochemical differences do not seem to be due to variations in the exogenous organic carbon supply between the 2 basins, but mostly due to the chemical quality of the vents or to the bacterial strain associated with the vent bivalves. In the North Fiji Basin, Ishibashi et al. (1994) noticed some fluctuations in water chemical composition between 2 sites prospected $150 \mathrm{~m}$ apart from each other They suggested that sub-seafloor fluid-rock interactions after phase segregation could considerably modify fluid composition. Although fluids venting in both Lau and North Fiji Basins belong to the same hydrothermal system, each site could offer specific chemical conditions (like the amount of energetic or toxic compounds), allowing different developments of the symbiotic associations. If this is the case, the great homogeneity of the mussel AARC composition collected at the 3 sites of Lau Basin suggests that fluids venting from these sites are chemically similar. Although hydrothermal activity was high at the Kayo site, stress index values of mussels collected in the North Fiji Basin seem to indicate that this basin offers 
less favourable conditions to the symbiotic bivalves than the Lau Basin.

Acknowledgements. We thank D. Desbruyères and A. M Alayse for their invitation to the 'Biolau' cruise (1989, IFREMER) and E. Ruellan and T Urabe for their invitation to the 'Yokosuka' cruise (1991, IFREMER-JAMSTEC). We thank the captains, crews and pilots of the 'Nadir', 'Nautile', 'Yokosuka' and 'Shinkai 6500 ' and the scientific teams for their assistance in collecting material. This study was supported by PNEHO grant and CNRS (LA117). Jeanne Beattie is gratefully acknowledged for her critical review of the English version.

\section{LITERATURE CITED}

Aftab, N. (1988). Amino acid composition of tissue protein from five species of oysters. Pak. J. Sci. ind. Res. 31(3): $200-202$

Albéric, P. (1986). Présence de quantités importantes de thiotaurine et d'hypotaurine dans les tissues de Riftia pachyptila (Pogonophore, Vestimentifère). C.r. Acad. Sci. Paris, t. 302, Sér. III, 13: 503-508

Albéric, P., Boulègue, J. (1990). Unusual amino compounds in the tissues of Calyptogena phaseoliformis (Japan Trench): possible link to symbiosis. Prog. Oceanogr. 24: 89-101

Allen, J. A., Garrett, M. R. (1971). Taurine in marine invertebrates. Adv. mar. Biol. 9: 205-253.

Allen, J. A. (1983). The ecology of deep-sea molluscs. In: Russell-Hunter, W D. (ed.) The Mollusca, Vol. 6. Academic Press, New York, p. 29-67

Awapara, J. (1976). The metabolism of taurine in the animal. In: Huxtable, R., Barbeau, A. (eds.) Taurine. Raven Press, New York, p. 1-19

Baginski, R. M., Pierce, S. K. (1975). Anaerobiosis: a possible source of osmotic solute for high-salinity acclimation in marine molluscs. J. exp. Biol. 62: 589-598

Baginski, R. M., Pierce, S. K. (1977). The time course of intracellular amino acid accumulation in the tissues of Modiolus demissius during high salinity adaptation. Comp. Biochem. Physiol. 57: 407-412

Bayne, B. L. (ed.) (1976). Marine mussels, their ecology and physiology. Cambridge University Press, London

Bayne, B. L., Brown, D. A., Burns, K., Dixon, D. R., Ivanovici, A., Livingstone, D. R., Lowe, D. M., Moore, M. N., Stebbing, A. R. D., Widdows, J. (1985). Biochemical measurements. In: Bayne, B. L. (ed.) The effects of stress and pollution on marine animals. Praeger Publishers, New York, p. $81-96$

Bayne, B. L., Widdows, J., Thompson, R. J. (1976). Physiological integrations. In: Bayne, B. L. (ed.) Marine mussels, their ecology and physiology. Cambridge University Press, London, p. 261-292

Belkin, S., Nelson, D. C., Jannasch, H. W. (1986). Symbiotic assimilation of $\mathrm{CO}_{2}$ in two hydrothermal vent animals, the mussel Bathymodiolus thermophilus and the tube worm Riftia pachyptila. Biol. Bull. 170: 110-121

Birkbeck, T. H., McHenery, J. G. (1982). Degradation of bacteria by Mytilus edulis. Mar. Biol. 72: 7-15

Bishop, S. H., Ellis, L. L., Burcham, J. M. (1983). Amino acid metabolism. In: Wilburg, K. M. (ed.) The Mollusca, Vol. 1. Academic Press, New York, p. 244-328

Brack, T. D., Smith, D. W., Madigan, M. T (1984). Biology of microorganisms, 4th edn. Prentice Hall, New York

Braun, V., Gnirke, H., Henning, U., Rehn, K. (1973). Model for structure of the shape-maintaining layer of the
Escherichia coli cell envelope. J. Bacteriol. June 114(3): $1264-1270$

Campbell, J. W., Bishop, S. H. (1970). Nitrogen metabolism in molluscs. In: Campbell, $\mathrm{J}$ W. (ed.) Comparative biochemistry of nitrogen metabolism. Academic Press, New York, p. 103-206

Cavallini, D., Frederici, G., Dupre, S., Canella, C., Scandurra, R. (1979). Ambiguities in the enzymology of sulfurcontaining compounds. Pure appl. Chem. 52: 147-155

Cavanaugh, C. M., Wirsen, C. O., Jannasch, H. W. (1992). Evidence for symbionts in a hydrothermal vent mussel (Bivalvia: Mytilidae) from the Mid-Atlantic Ridge. Appl. environ. Microbiol. 58(12): 3799-3803

Childress, J. J., Fisher, C. (1992). The biology of hydrothermal vents animals - physiology, biochemistry and autotrophic symbiosis. Oceanogr. mar. Biol. A. Rev. 30: $337-441$

Dando, P. R., Southward, A. J., Southward, E. C., Barrett, R. L. (1986). Possible energy sources for chemoautotrophic procaryotes symbiotic with invertebrates from a Norwegian fjord. Ophelia 26: 135-150

Desbruyères, D., Alayse-Danet, A. M., Otha, S., and the scientific parties of Biolau and Starmer cruises (1994). Deepsea hydrothermal communities in Southwestern Pacific back-arc basins (the North-Fidji and Lau Basins): composition, microdistribution and food-web. In: Auzende, J.-M., Urabe, T. (eds.) North Fiji Basin: STARMER FrenchJapanese program. Mar. Geol. 116: 227-242

De Zwaan, A. (1983). Carbohydrate catabolism in bivalves. In: Wilburg, K. M. (ed.) The Mollusca, Vol. 1. Academic Press, New York, p. 138-176

De Zwaan, A., Van Marrewijk, W. J. A. (1973). Intracellular localization of pyruvate carboxylase, phosphoenolpyruvate carboxykinase and 'malic enzyme' and the absence of glyoxylate cycle enzymes in the sea mussel (Mytilus edulis L.). Comp. Biochem. Physiol. 44B: 1057-1066

Felbeck, H. (1983). Sulfide oxydation and carbon fixation by the gutless clam Solemya reidi: an animal-bacteria symbiosis. J. comp. Physiol. 152: 3-11

Felbeck, H., Childress, J. J. (1983). Biochemical interactions between molluscs and their algal and bacterial symbionts In: Hochachka, P. W. (ed.) The Mollusca, Vol. 2, Environmental biochemistry and physiology. Academic Press, New York, p. 331-358

Fiala-Médioni, A. (1988). Synthèses sur les adaptations structurales et fonctionnelles liées à la nutrition des mollusques bivalves des sources hydrothermales profondes. Oceanol. Acta 8: 172-177

Fiala-Médioni, A., Alayse, A. M., Cahet, G. (1986a). Evidence of in situ uptake and incorporation of bicarbonate and amino acids by an hydrothermal vent mussel. J. exp. mar. Biol. Ecol. 96: 191-198

Fiala-Médioni, A., Felbeck, H. (1990). Autotrophic process in invertebrate nutrition: bacterial symbiosis in bivalve molluscs. In: Mellinger, J., Truchot, P. P., Lahlou, B. (eds.) Animal nutrition and transport processes. Comparative physiology. Karger, Basel, p. 49-69

Fiala-Médioni, A., Felbeck, H., Childress, J. J., Fisher, C. R. Vetter, R. D. (1989). Lysosomic resorption of bacterial symbionts in deep-sea bivalves. In: Nardon, P., GianinazziPearson, V., Grenier, A. M., Margulis, L., Smith, D. C. (eds.) 4th International Colloquium on Endocytobiology and Symbiosis, Villeurbanne. INRA, Paris, p. 335-338

Fiala-Médioni, A., Le Pennec, M. (1987). Trophic structural adaptations in relation to the bacterial association of bivalve molluscs from hydrothermal vents and subduction zones. Symbiosis $4: 63-74$ 
Fiala-Médioni, A., Métivier, C., Herry, A., Le Pennec, M (1986b). Ultrastructure of the gill of the hydrothermal vent mytilid Bathymodiolus sp. Mar. Biol. 92: 65-72

Fiala-Médionı, A., Michalski, J. C., Jollès, J., Alonso, C., Montreuil, J. (1994). Lysosomic and lysosyme activities in gill of bivalves from deep hydrothermal vents. C.r. Acad. Sci., Paris Sér. III 317: 239-244

Fisher, C. R., Brooks, J. M., Vodenichar, J. S., Zande, J. M., Childress, J. J., Burke, R. A. (1993). The co-occurence of methanotrophic and chemoautotrophic sulfur-oxidizing bacterial symbionts in a deep-sea mussel. Mar. Ecol. 14: $277-289$

Fisher, C. R., Childress, J. J. (1986). Translocation of fixed carbon from symbiotic bacteria to host tissues in the gutless bivalve Solemya reidi. Mar. Biol. 93: 59-68

Fisher, C. R., Childress, J. J. (1992). Organic carbon transfer from methanotrophic symbionts to the host hydrocarbonseep mussel. Symbiosis 12: 221-235

Fisher, C. R., Childress, J. J., Oremland, R. S., Bidigare, R. R (1987). The importance of methane and thiosulfate in the metabolism of the bacterial symbionts of two deep-sea mussels. Mar. Biol. 96: 59-71

Fouquet, Y., Von Stackelberg, U., Charlou, J. L., Donval, J. P. Erzinger, J., Foucher, J. P., Herzig, P., Mühe, R., Soakai, S. Wiedicke, M., Withechurch, H. (1991). Hydrothermal activity and metallogenesis in the Lau back-arc basin. Nature 349: $778-780$

Gabbott, P. A. (1976). Energy metabolism. In: Bayne, B. L. (ed.) Marine mussels, their ecology and physiology. Cambridge University Press, London, p. 293-337

Hartmann, E., Konig. H. (1990). Comparison of the biosynthesis of the methanobacterial pseudomurein and the eubacterial murein. Naturwissenschaften 77: 472-475

Hebeler, B. H., Young, F. E. (1976). Chemical composition and turnover of peptidoglycan in Nesseria gonorrhoeae. J. Bacteriol. 126(3): 1180-1185

Henrichs, S. M., Cuhel, R. (1985). Occurrence of $\beta$-aminoglutaric acid in marine bacteria. Appl. environ. Microbiol. 50(2): $543-545$

Ishibashi, J., Grimaud, D., Nojiri, Y., Auzende, J. M., Urabe, T (1994). Fluctuation of chemical composition of the phaseseparated hydrothermal fluid from the North Fidji Basin Ridge. Mar. Geol. 116: 215-226

Jeffries, H. P. (1972). A stress syndrome in hard clam, Mercenaria mercenaria. J. Invertebr. Pathol. 20: 242-251

Jørgensen, C. B. (ed.) (1990). Bivalves filter feeding: hydrodynamics, bioenergetics, physiology and ecology. Olsen \& Olsen, Fredensborg

Koehn, R. K. (1991). The genetics and taxonomy of species in the genus Mytilus. Aquaculture 94: 125-146

Lehninger, A. L. (1981). Biochimie, 2nd edn. Flammarion, Paris

Livingstone, D. R. Widdows, J., Fieth, P. (1979). Aspect of nitrogen metabolism of the common mussel Mytilus edulis: adaptation to abrupt and fluctuating changes in

This article was submitted to the editor salinity. Mar. Biol. 53: 41-55

Melaouah, N. (1990). Absorption et métabolisation de substances organiques dissoutes au cours du développement larvaire de Mytilus edulis L. (Bivalves). Oceanol. Acta 13(2): $245-255$

Mopper, K., Dawson, R. (1986). Determination of amino acids in sea water - recent chromatographic developments and future directions. Sci. tot. Environ. 49: 115-131

Mopper, K., Lindroth, P. (1982). Diel and depth variations in dissolved amino acids and amonium in the Baltic Sea determined by shipboard HPLC analysis. Limnol. Oceanogr. 27: $336-347$

Moriarty, D. J. W. (1983). Measurement of muramic acid in marine sediments by high performance liquid chromatography. J. microbiol. Meth. 1. 111-117

Page, H. M., Fiala-Médioni, A., Fisher, C. R., Childress, J. J. (1991). Experimental evidence for filter-feeding by the hydrothermal vent mussel, Bathymodiolus thermophilus. Deep Sea Res. 38: 1455-1461

Phillips, N. W. (1984). Role of different microbes and substrates as potential suppliers of specific, essential nutrients to marine detritivores. Bull. mar. Sci. 35: 283-298

Powell, M. A., Somero, G. N. (1983). Blood components prevent sulfide poisoning of respiration of the hydrothermal vent tube worm, Riftia pachyptila. Science 219: 297-299

Prieur, D. (1981). Experimental studies of trophic relationships between marine bacteria and bivalve molluscs. Kiel. Meerestorsch. Sonderh. 5: 376-383

Riley, R. T (1980). The effect of prolonged starvation on the relative free amino acid composition of the extracellular body fluids and protein bound amino acids in the oyster, Crassostrea gigas. Comp. Biochem. Physiol. 67: 279-281

Russell-Hunter, W. D. (1983). Overview: planetary distribution of and ecological constaints upon the mollusca. In: Russell-Hunter, W. D. (ed.) The Mollusca, Vol. 6. Academic Press, New York, p. 1-25

Schleifer, K. H., Kandler, O. (1972). Peptidoglycan types of bacterial cell walls and their taxonomic implications. Bacteriol. Rev. 36(4): 407-477

Shurnway, S. E., Youngson, A. (1979). The effect of fluctuating salinity on physiology of Modiolus demissius. J. exp. mar. Biol. Ecol 40: 167-181

Stephen, G. C. (1972). Amino acid accumulation and assimilation in marine organisms. In: Campbell, J. W., Goldstein, L. (eds.) Nitrogen metabolism and the environment. Academic Press, New York, p.155-184

Von Cosel, R., Métivier, B., Hashimoto, J. (1994). Three new Bathymodiolus (Bivalvia: Mytilidae) from hydrothermal vents in the Lau Basin and the North Fidji Basin, Western Pacific, and the Snake Pit area, Mid-Atlantic Ridge. Veliger 37: 374-392

Zhang, C.-H., Hirano, T., Suzuki, T., Shirai, T., Suyama, M. (1991). Amino acid composition of adductor muscle proteins of bivalves. J. Tokyo Univ. Fish. 78: 27-33

Manuscript first received: August 15, 1994

Revised version accepted: January 2, 1995 